\title{
Ag-Al-Sn 合金による純チタンの低温ろら接
}

\author{
竹下 晋 正* 高 田 壽*
}

J. Japan Inst. Metals, Vol. 55, No. 3 (1991), pp. 330-336

Low Temperature Brazing of Titanium with Silver-Aluminum-Tin Filler Alloys

Kunimasa Takeshita* and Hisashi Takada*

In this investigation, Ag-Al-Sn filler alloys are identified to allow the brazing of titanium at a temperature well below its $\alpha-\beta$ transformation temperature of $1155 \mathrm{~K}$ and to afford good strength of the brazed joint.

$\mathrm{Sn}$ addition to $\mathrm{Ag}-\mathrm{Al}$ filler alloys has a significant effect on the drop of their liquidus temperatures and the improvement in wetting to the base metal of titanium.

The tensile strength of butt-joint specimens brazed with Ag-5, 10, 15 mass\% $\mathrm{Al}$ filler alloys containing 2.5 or 5 mass $\% \mathrm{Sn}$ are, however, 100 to $170 \mathrm{MPa}$ lower than or equal to those brazed with Ag-5, 10, 15 mass\% $\mathrm{Al}$ filler alloys.

In the case of the $\mathrm{Ag}-20$ mass\% $\mathrm{Al}$ filler alloy, Sn addition by 2.5 mass\% to this filler alloy improves the tensile strength of the brazed butt-joint specimen, the value of which is $290 \mathrm{MPa}$. Furtheremore, the Ag-20 mass\%Al-2.5 mass\% Sn filler alloy enables titanium to be brazed at $1000 \mathrm{~K}$, which is $155 \mathrm{~K}$ lower than the $\alpha$ $\beta$ transformation temperature of titanium.

(Received October 13, 1990)

Keywords: brazing, titanium, silver-base filler alloy, silver-aluminum-tin alloy, joint strength, wetting behavior

I . 緒言

チタン怙よびチタン合金のろら接にはチタン系，ジルコ ニウム系, 銀系, アルミニウム系合金がろう材として用い られる.チタン系, ジルコニウム系合金の場合は継手強度 が高く，耐食性も優れたろら材であるが，ろら接温度が高 く $1223 \mathrm{~K}$ 程度である(1)-(3). しかしながらチタンおよび チタン合金を $\alpha-\beta$ 変態点 (チタンの $\alpha-\beta$ 変態点は $1155 \mathrm{~K}$ ) 以上の高温で行うろら接では，母材の組織変化による特性 の劣化や, 变態時の約 $5.5 \%$ の体積変化によって発生する 応力による接合部での欠陷導入などの問題が生じる恐れが ある、そのため銀系(2)(4)(5)あるいはアルミニウム系 ${ }^{(6)}$ 合金 をろら材として用いた，チタンおよびチタン合金の低温ろ ら接に向けた研究が最近行われてきている.アルミニウム 系合金をろら材に用いた場合には，ろら接温度は933〜 $943 \mathrm{~K}$ と低温であるが，継手のせん断強度は 73〜90 $\mathrm{MPa}$ と低い(6). 一方，銀系合金の例えば Ag-5 mass\% Al0.5 mass\% $\mathrm{Mn}$ 合金をろら材に用いた場合には，継手のせ 几断強度は $142 \sim 176 \mathrm{MPa}$ と高くなるが，ろら接温度も 1113〜1173 K と高くなる ${ }^{(5)}$.

そこで本研究では, ろう接継手の強度を低下させること
なく, ろら接温度をチタンの $\boldsymbol{\alpha} \boldsymbol{\beta} \boldsymbol{\beta}$ 変態点以下の温度とする 目的で, $\mathrm{Ag}-\mathrm{Al}$ 合金に第 3 元素として Snを添加した Ag$\mathrm{Al}-\mathrm{Sn}$ 合金によるチタンの低温ろら接を試みる.

\section{II. 実 験 方 法}

母材は板厚 $1.5 \mathrm{~mm}$ の第 1 種チタンで $0.2 \%$ 耐力は 350 $\mathrm{MPa}$ ，引張強度は $420 \mathrm{MPa}$ である.

ろら材作製のため純度 $99.9 \%$ の銀，純度 $99.99 \%$ のル ミニウムおよびすずを用いて 12 種類の母合金を大気中で 溶製した。母合金中のアルミニウム濃度は $5,10,15,20$ mass\%で，その各々に対してすずの濃度は $0,2.5,5$ mass\%である.

母合金の組成は発光分光分析，液相線および固相線温度 は熱分析, 晶出相の同定は $\mathrm{CuK}_{\alpha}$ 線による $\mathrm{X}$ 線回折, 硬 さはビッカース硬度計(荷重 $4.9 \mathrm{~N}$, 測定時間 $15 \mathrm{~s}$ ) で測定 した. 母合金はアルミナ板上で再溶解し，銅製ピストンで 凝固することにより厚さ $0.1 \sim 0.2 \mathrm{~mm}$ の薄片とし，ろう 接に使用した.

ろら材のチタンに対するぬれの良否は広がり指数で判定 した. $20 \mathrm{~mm} \times 20 \mathrm{~mm}$ のチタン板上に約 $5 \mathrm{~mm}^{3}$ のろら材 を置き，真空中で液相線温度以上の設定温度で $900 \mathrm{~s}$ 保持

* 福井大学工学部機械工学科(Department of Mechanical Engineering, Faculty of Engineering, Fukui University, Fukui) 
した後炉中冷却し，ろら材の広がった面積 $A$ を測定した. ろら材は溶融時に球状の液滴になると仮定し, そのチタン 板への投影面積を $A_{0}$ とするならば，広がり指数は $A / A_{0}$ で表わされる.

ろら接強度は突合せ継手の引張強度で評価した。試験片 寸法はJIS 6 号試験片に準拠し, 試験速度は $0.06 \mathrm{~mm} / \mathrm{s}$ とした．Fig. 1 にろう接継手の寸法を示す．継手の角の 部分は，継手を突き合わせた状態で間隙に厚さ $50 \mu \mathrm{m}$ の チタン箔をはさみ，この部分を耐熱セメントで固定するこ とにより母材間の間隙を $50 \mu \mathrm{m}$ に設定するためのもので ある. 角の部分はろら接後放電加工機で切断し，ろら接部 の光学顕微鏡による組織観察(硝酸と弗酸の混合水溶液で $20 \mathrm{~s}$ 腐食)，マイクロ・ビッカース硬度計による硬さ測定 (荷重 $98 \mathrm{mN}$, 測定時間 $15 \mathrm{~s}$ ), X 線マイクロ・アナライ ザー (EPMA)による元素濃度線分析に用いた。ささらにろ ら接部での微小焦点 $\mathrm{X}$ 線回折 $\left(\mathrm{CuK}_{\alpha}\right.$ 線, 焦点径 $\left.30 \mu \mathrm{m}\right)$ により，ろら材内部と接合界面部の結晶相の同定を行っ た.引張試験後，継手部破断面を走査型電子顕微鏡 (SEM) で観察し, 同時にエネルギー分散 $\mathrm{X}$ 線分光器

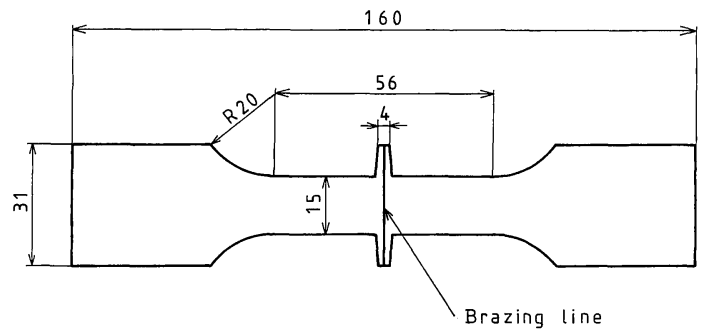

Fig. 1 Shape and size of the brazed butt-joint specimen used for the tension test.
(EDX) で破断面の元素濃度分析を行った. くわえて継手 部破断面での微小焦点 $\mathrm{X}$ 線回折 $\left(\mathrm{CuK}_{\alpha}\right.$ 線，焦点径 100 $\mu \mathrm{m})$ により破断面に存在する結晶相の同定を行い，ろら接 部での破断位置を特定した。

ろら接継手作製およびぬれ性試験時の真空度は $8 \times 10^{-3}$ $\mathrm{Pa}$ であり，設定温度までの昇温速度は $1 \mathrm{~K} / \mathrm{s}$ ，設定温度 からの冷却速度は $2 \mathrm{~K} / \mathrm{s}$ である。ろら接温度は前述した 広がり指数の値が10〜35 となる温度 (Fig. 2 および Table 1参照)とし，ろら接時間は $900 \mathrm{~s}$ とした。 ろら接 温度は Table 1 に示すように，いずれのろら材の場合もチ タンの $\alpha-\beta$ 変態点 $1155 \mathrm{~K}$ 以下である.

\section{III. 実験結果と考察}

\section{1. ろう材の組成と特性}

ろう材の組成と特性を Table 1 に示す．ろう材中の Al

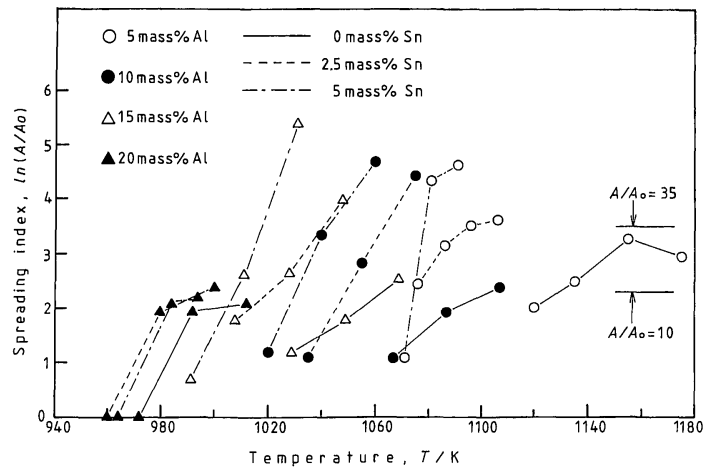

Fig. 2 Variation in spreading index with temperature.

Table 1 Composition, characteristics and brazing temperature of filler alloys.

\begin{tabular}{|c|c|c|c|c|c|c|c|c|}
\hline \multirow{2}{*}{$\begin{array}{l}\text { Alloy } \\
\text { Number }\end{array}$} & \multicolumn{3}{|c|}{ Composition (mass\%) } & \multirow{2}{*}{ Phase } & \multirow{2}{*}{$\begin{array}{l}\text { Hardness } \\
(H v)\end{array}$} & \multirow{2}{*}{$\begin{array}{c}\text { Liquidus } \\
\text { Temperature } \\
(\mathrm{K})\end{array}$} & \multirow{2}{*}{$\begin{array}{c}\text { Solidus } \\
\text { Temperature } \\
(\mathrm{K})\end{array}$} & \multirow{2}{*}{$\begin{array}{c}\text { Brazing } \\
\text { Temperature } \\
(\mathrm{K})\end{array}$} \\
\hline & $\mathrm{Ag}$ & $\mathrm{Al}$ & $\mathrm{Sn}$ & & & & & \\
\hline 1 & bal. & 4.6 & 0 & $\alpha, \mu$ & 49 & 1105 & 1060 & 1136 \\
\hline 2 & bal. & 4.6 & 2.4 & $\alpha, \beta, \mu$ & 53 & 1076 & 901 & 1083 \\
\hline 3 & bal. & 4.6 & 4.7 & $\alpha, \beta, \mu$ & 59 & 1041 & 922 & 1077 \\
\hline 4 & bal. & 9.7 & 0 & $\zeta, \mu$ & 80 & 1017 & 1000 & 1110 \\
\hline 5 & bal. & 9.2 & 2.4 & $\zeta, \mu$ & 91 & 985 & 982 & 1057 \\
\hline 6 & bal. & 9.4 & 4.8 & $\zeta, \mu, \gamma$ & 95 & \multicolumn{2}{|c|}{970} & 1034 \\
\hline 7 & bal. & 14.2 & 0 & $\zeta, \delta$ & 107 & \multicolumn{2}{|c|}{977} & 1090 \\
\hline 8 & bal. & 14.0 & 2.5 & $\zeta, \delta, \gamma$ & 156 & \multicolumn{2}{|c|}{958} & 1032 \\
\hline 9 & bal. & 14.0 & 4.8 & $\zeta, \delta, \gamma$ & 149 & \multicolumn{2}{|c|}{941} & 1015 \\
\hline 10 & bal. & 19.3 & 0 & $\zeta, \delta$ & 112 & 922 & 854 & 1045 \\
\hline 11 & bal. & 19.3 & 2.4 & $\zeta, \delta, \gamma$ & 101 & 910 & 819 & 1000 \\
\hline 12 & bal. & 19.1 & 4.7 & $\zeta, \delta, \gamma$ & 99 & 894 & 805 & 997 \\
\hline
\end{tabular}


濃度のいかんにかかわらず, Sn の添加はろら材の液相線 温度を低下させるのに効果がある. 5 mass $\% \mathrm{Sn}$ の添加に よる液相線温度の降下は $28 \sim 64 \mathrm{~K}$ で，ろら材中の $\mathrm{Al}$ 濃 度が低いほど液相線温度の降下は大きい。

ろら材中の晶出相(7) としては $\alpha$ 相(面心立方晶, $\mathrm{Ag}$ 固 溶体), $\boldsymbol{\beta}$ 相(最密六方晶, $\mathrm{Ag}-\mathrm{Sn}$ ), $\boldsymbol{\gamma}$ 相(斜方晶, $\mathrm{Ag}_{3} \mathrm{Sn}$ ), $\delta$ 相 (面心立方晶, $\mathrm{Al}$ 固溶体), $\zeta$ 相 (最密六方晶, $\mathrm{Ag}_{2} \mathrm{Al}$ ) および $\mu$ 相 $\left(\beta-\mathrm{Mn}\right.$ 構造, $\left.\mathrm{Ag}_{3} \mathrm{Al}\right)$ が確認された。 ろら材 1〜3 では $\alpha$ 相が主であるが, Sn 濃度が増加するにつれて $\beta, \mu$ 相 の割合が増加し，ろう材の硬度は若干高くなる. ろら材 4〜6ではら相が主であり, Sn 濃度が増加するにつ れて $\mu, \gamma$ 相の割合が増加するため硬度はろら材 $1 \sim 3$ の硬 度よりも高くなる．ろら材 $7 \sim 9$ ではと相が主であり，Sn 濃度が増加するにつれて $\gamma$ 相の割合がかなり増加するため に硬度は非常に高くなり，ろら材は脆くなる。乃ら材 10〜12は晶出相に関してはろら材 7〜9 と同様であるが, この場合は $\delta$ 相の割合が多く $\boldsymbol{\gamma}$ 相の割合は少ないために 硬度はろら材 7〜9 の硬度ほど高くない.

\section{2. ろう材のチタンに対するぬれ}

Fig. 2 に広がり指数と試験温度の関係を示す．いずれの ろら材も試験温度が高くなるにつれて広がり指数は増加す る. Snを含まないろう材では，ろら材中の $\mathrm{Al}$ 濃度が増 加するにつれて広がり指数が低下し，ぬれが悪くなる．し
かしながら $\mathrm{Sn}$ を含んだろら材では，いずれの $\mathrm{Al}$ 濃度の ろら材の場合でも，ろう材中の Sn 濃度が増加するにつれ て広がり指数の温度に対する増加率が上昇し, Snの添加 がろら材のチタンへのぬれの向上に有効なことが分かる.

\section{3. ろう接部の組織と元素濃度分布}

ろら接部の組織を Fig. 3 に， ろら接部での元素濃度分 布をFig. 4 亿示す.

Ag-5 mass $\% \mathrm{Al}$ のろら材 1 では，ろら材内部は $\mathrm{Al}$ が固 溶した $\alpha$ 相(面心立方晶, $\mathrm{Ag}$ 固溶体)と少量の $\gamma$ 相(正方 晶, $\mathrm{TiAl})$ で構成され，接合界面部には $\mathrm{Ag}$ が固溶した層 状の $\gamma$ 相と $\delta$ 相 (最密六方晶, $\mathrm{Ti}_{3} \mathrm{Al}$ ) が形成される.この 合金に 5 mass\%の Snを添加したろら材 3 では，ろう材 内部は $\mathrm{Al}$ と $\mathrm{Sn}$ が固溶した $\alpha$ 相と $\gamma$ 相で構成される。接 合界面部には $\mathrm{Sn}$ の濃化によって形成された $\beta$ 相 (最密 六方晶, $\mathrm{Ag}-\mathrm{Sn})$ と $\gamma$ 相, $\delta$ 相が層状に存在する. 2.5 mass\%の Snを含んだろら材 2 は，ろう材 3 の場合と同 様である.

Ag-10 mass $\% \mathrm{Al}$ のろら材 4 では，ろら材内部は $\mathrm{Al}$ が

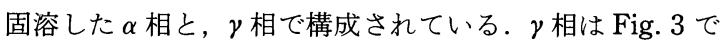
ろら材内部に黒く分散する相である。接合界面部には Fig. 3 では識別が困難であるが，Fig. 4 からは二つの相が 層状に生成していることが分かる． $\mathrm{Al}$ の濃度分布と，接 合界面部での微小焦点 X 線回折の結果から，母材側の生

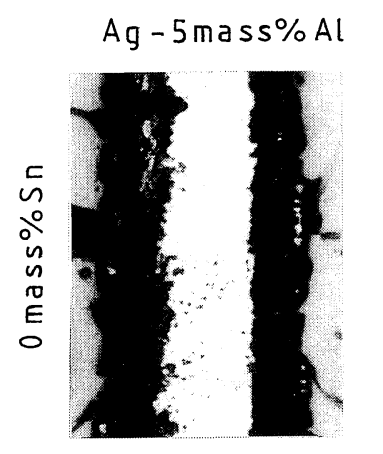

\section{$\mathrm{Ag}-10 \mathrm{mass} \% \mathrm{Al}$}
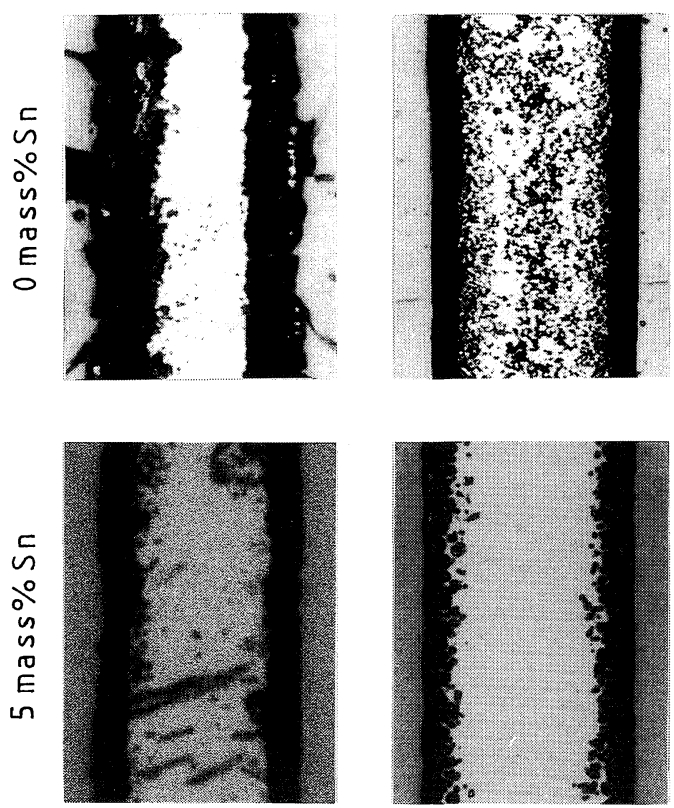

Ag-15 mass \% Al
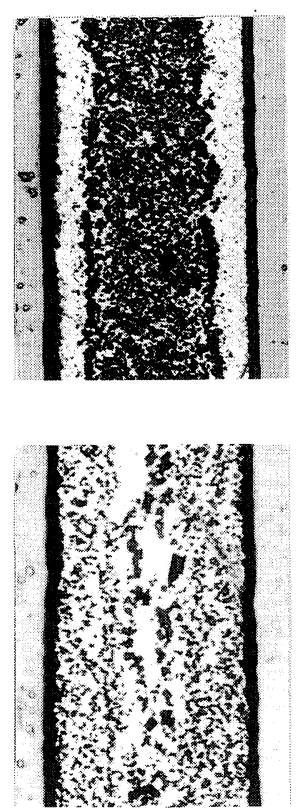

$\mathrm{Ag}-20 \mathrm{mass} \% \mathrm{Al}$
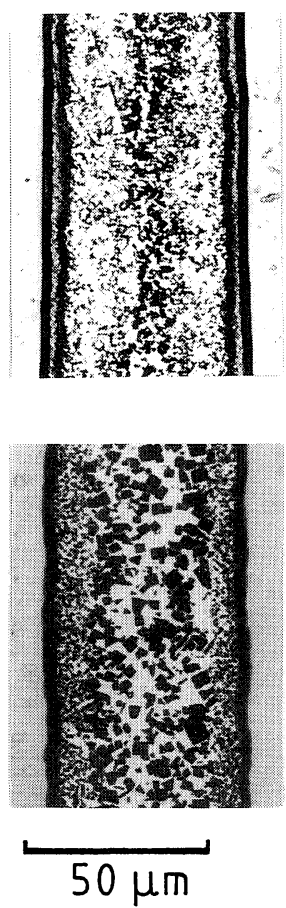

Fig. 3 Optical micrographs of the joints brazed with $\mathrm{Ag}-\mathrm{Al}$ and $\mathrm{Ag}-\mathrm{Al}-\mathrm{Sn}$ filler alloys. 

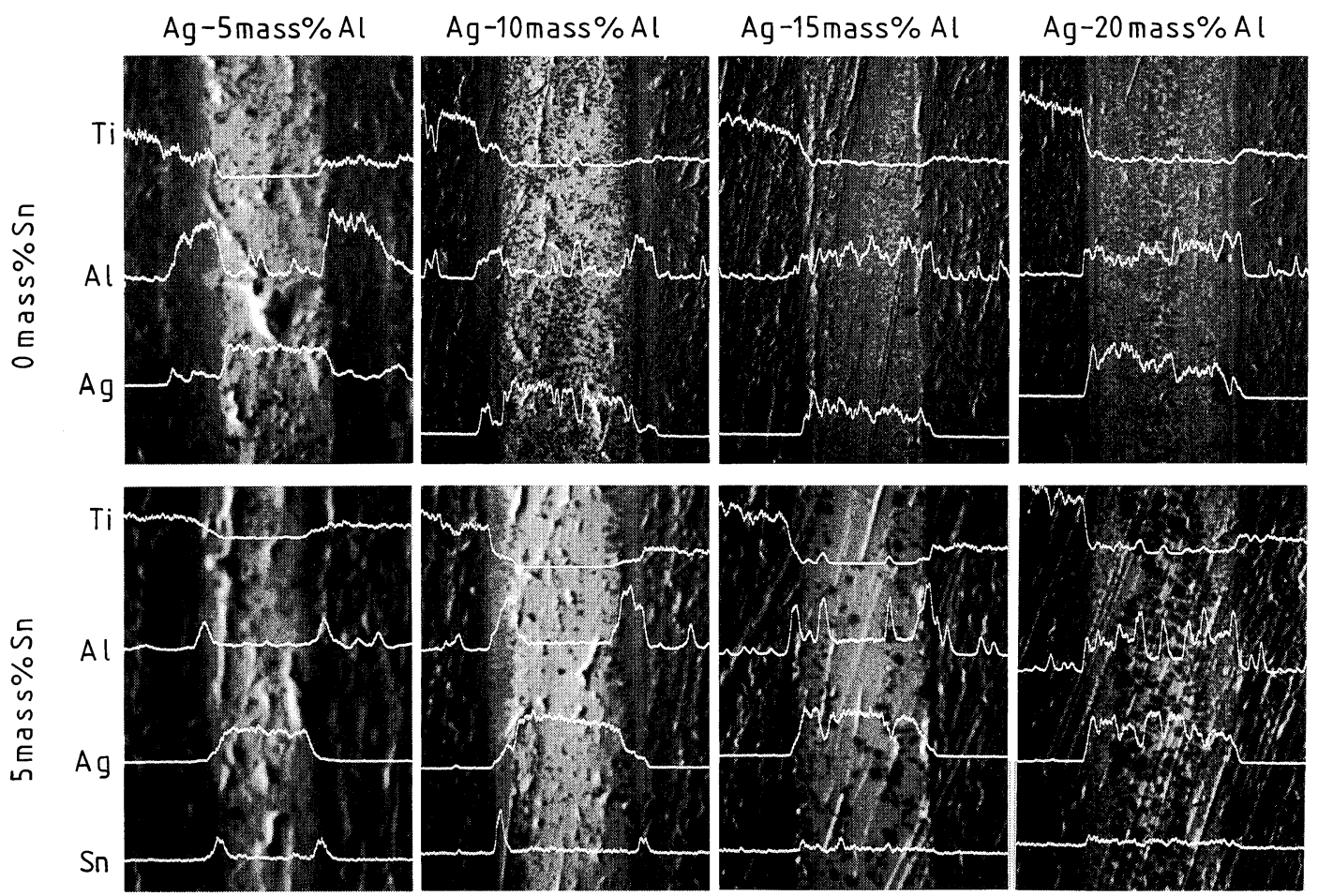

Fig. 4 Electron microprobe traces across the joints brazed with Ag-Al and Ag-Al-Sn filler alloys.

成相は $\boldsymbol{\delta}$ 相で，ろら材側の生成相は $\gamma$ 相であることが分 かる.この合金に 5 mass\%の Snを添加したろら材 6 で は，ろら材内部は $\mathrm{Al}$ と $\mathrm{Sn} か ゙$ 固溶した $\alpha$ 相である。接合 界面部には二つの化合物が層状に生成していることが Fig. 4 から分かる.母材側の相は接合界面部への Sn の濃 化によってかなり $\mathrm{Sn}$ を固溶した $\delta$ 相であり，ろら材側に 島状に生成した相は $\gamma$ 相である. 2.5 mass\%の Sn を含ん だろう材 5 は， ろら材 6 の場合と同様である.

Ag- 15 mass\% $\%$ al のろら材 7 では, ろら材内部は $\mathrm{Al}$ が 固溶した $\alpha$ 相と, $\gamma$ 相で構成されている. 接合界面部には $\gamma$ 相が層状に生成し， $\gamma$ 相の内側には，Fig. 3 で白く見え る $\alpha$ 相が存在する。この合金に 5 mass\%の Snを添加し たろら材 9 では, ろら材内部は Sn が固溶した母相のら相 (最密六方晶, $\mathrm{Ag}_{2} \mathrm{Al}$ ) と, この相内に分散する $\gamma$ 相で構成 されている. 接合界面部には $\gamma$ 相が層状に生成している.

一方 2.5 mass\%の Sn を含んだろう材 8 では, 接合界面 部にはろら材 9 の場合と同様に $\gamma$ 相が層状に生成してい るが，ろら材内部は $\mathrm{Al}$ と $\mathrm{Sn} か ゙$ 固溶した母相の $\alpha$ 相と, この相内に分散する $\gamma$ 相抢よびら相で構成されている.

Ag-20 mass\% $\%$ l のろら材10では，ろら材内部は母相の $\zeta$ 相と, この相内に分散する $\gamma$ 相で構成されている. 接合 界面部には Fig. 3 および Fig. 4 で確認されるように三つ の生成相が層状に存在する. $\mathrm{Al}$ の濃度分布之接合界面部 での微小焦点 X 線回折の結果から，母材側とろら材側に $\gamma$ 相が，それらの $\gamma$ 相の間にら相が生成していることが分 かる.

この合金に 5 mass\%の Sn を添加したろら材 12 では, ろら材中央部は母相の 相と Fig. 3 で黒い矩形状に見兄 る $\gamma$ 相で構成され, その両側の部分は $\zeta$ 相と $\delta$ 相で構成さ れている. 接合界面部には層状の $\gamma$ 相と $\delta$ 相が存在する.

2.5 mass\% $\%$ Sn を含んだろら材 11 はほとんどろう材 12 の場合と同様であるが，接合界面部に生成する化合物相の

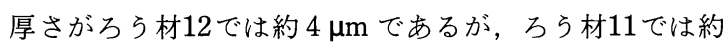
$1 \mu \mathrm{m}$ と薄い点で異なっている。

\section{4. ろう接部の硬度分布}

\section{ろら接部の硬度分布を Fig. 5 亿示す.}

Ag-5 mass\% $\%$ l のろら材 1 では，ろら材内部の組織が 主に $\mathrm{Al}$ が固溶した $\alpha$ 相であり，その硬度は $H v 70$ 程度で あるが， 5 mass\%の Sn を含んだろら材 3 では，万ら材内 部の組織が $\mathrm{Al}$ 抢よび $\mathrm{Sn}$ を固溶した $\alpha$ 相内に $\gamma$ 相が分散 するようになるため硬度は $H v 110$ に増加する．万ら材 1 では接合界面部に $\gamma$ 相と $\delta$ 相が生成し界面部の硬度は $H v 350$ であるが，万弓材 3 では $\beta$ 相も生成するために界 面部の硬度は $H v 290$ 亿低下している.

$\mathrm{Ag}-10$ mass\% $\% \mathrm{Al}$ の場合, Snの含有量によらずろう材 内部の硬度は $H v 100$ 程度, 接合界面部の硬度は $H v 320$ であり，硬度分布の形状も良く似通っている。 


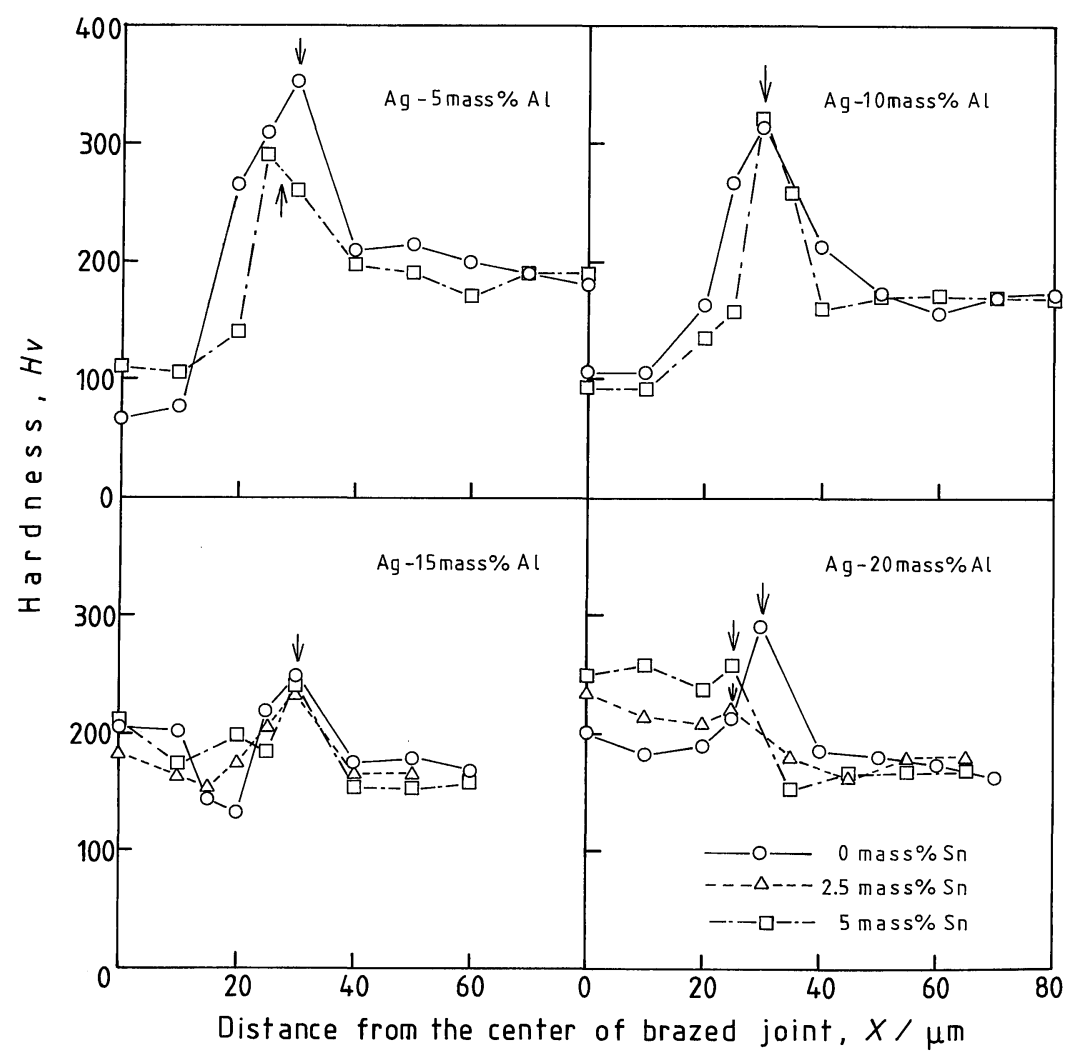

Fig. 5 Microhardness traverse across the joints brazed with Ag-Al and Ag-Al-Sn filler alloys. Note that arrow indicates the position of interface between filler alloy and base metal.

Ag-15 mass\% $\mathrm{Al}$ のろら材 7 では，万ら材中央部は $\alpha$ 相 に微細な $\gamma$ 相が分散した組織となっているために，その硬 度は $H v 200$ とかなり高いが，接合界面部付近は層状の $\alpha$ 相が存在し, 硬度は $H v 110$ 亿低下している.

Sn 2.5 mass\%含む万ら材 8 では，万ら材内部に $\gamma$ 相 やら相が存在するものの，ろら材 7 と比べて $\alpha$ 相の割合 が多いために，その硬度は $H v$ 150～180 とろら材 7 の場 合のろら材中央部の硬度よりも低下する。しかしながら Sn 5 mass\%含むろう材 9 では，ろら材内部が母相の 相内に $\gamma$ 相が分散した組織のため，その硬度は Hv180〜 200 と高くなっている. Snの含有量によらず接合界面部 には $\gamma$ 相が存在し，接合界面部の硬度は $H v 230 \sim 250$ と ろら材内部の硬度に比べて若干高くなっている.

Ag-20 mass\% $\%$ l のろら材10では, ろら材内部は母相の 相と,この中に分散する $\gamma$ 相で構成されており，その硬 度は $H v$ 180 200 とかなり高く，接合界面部には $\gamma$ 相が 存在するために硬度は $H v 290$ と, 万ら材内部の硬度より もさらに高くなっている. Snを 2.5 mass\%含むろう材 11 では，万ら材中央部は $\zeta$ 相， $\gamma$ 相抢よび $\delta$ 相で，その両側 が 210〜230 とろう材10の場合のろう材内部の硬度に比べて
高くなっている，接合界面部には $\gamma$ 相と $\delta$ 相が存在する が，その厚さが $1 \mu \mathrm{m}$ とかなり薄いために，界面部の硬度 は $H v 220$ とろら材内部の硬度とほとんど变わらない。

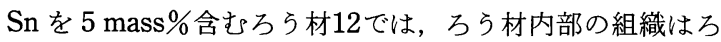
ら材 11 の場合と变わらない．しかしながらろら材中の $\mathrm{Sn}$ の含有量が増加すると, 相内に固溶する $\mathrm{Sn}$ 量が増加し, ろら材内部の硬度は $H v 240 \sim 260$ とろら材 11 の場合のろ ら材内部の硬度よりも高くなる。

\section{5. 万う接継手の引張強度}

Fig. 6 亿各ろら材でろら接された継手の引張強度およ び破断位置を示す。破断面の SEM 観察の結果，破断はい ずれの場合も接合界面部付近で生じたことが確認された。

さらに継手部破断面での微小焦点 X 線回折の結果から， 破断面に存在する結晶相はろら材 $1,2,3,4,5,6,11,12 て ゙$ は $\gamma$ 相と $\delta$ 相，ろら材 $7,8,9,10$ では $\gamma$ 相と Ti であるこ とが確認された. Fig. 6 で例光ば $(1, \gamma-\delta)$ の記号は，万弓 材 1 では破断は接合界面部に生成した $\gamma$ 相と $\delta$ 相との界 面で生じたことを示している.

$\mathrm{Sn}$ を含まない $\mathrm{Ag}-\mathrm{Al}$ 系ろら材 (ろら材 $1,4,7,10$ ) でろ ら接された継手の引張強度は, 万ら材 4 の場合が 340 


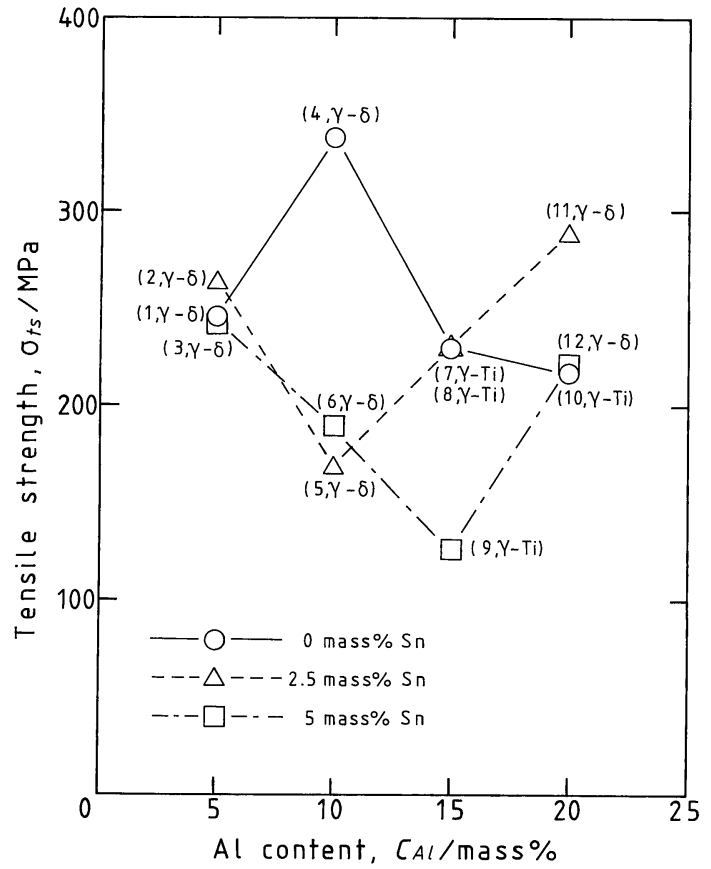

Fig. 6 Variation in tensile strength of the brazed specimen with $\mathrm{Al}$ and $\mathrm{Sn}$ contents in the $\mathrm{Ag}$-base filler alloy.

$\mathrm{MPa}$ と最も高く，他の場合は 220〜 $250 \mathrm{MPa}$ とほぼ同程 度である.

$\mathrm{Ag}-\mathrm{Al}$ 系ろ 材に $\mathrm{Sn}$ を添加すると, $\mathrm{Ag}-5$ mass $\% \mathrm{Al}$ 系 のろら材 2,3 では引張強度はそれぞれ $260,240 \mathrm{MPa}$ と $\mathrm{Sn}$ を含まないろう材 1 での引張強度 $250 \mathrm{MPa}$ と同程度
である。しかしながら Ag-10 mass\%Al 系のろう材 5, 6 では，引張強度はそれぞれ $170,190 \mathrm{MPa}$ と $\mathrm{Sn}$ を含まな いろら材 4 での引張強度 $340 \mathrm{MPa}$ よりも $150 \sim 170 \mathrm{MPa}$ も低下する. Ag- 15 mass\% Al 系のろら材 8,9 では，ろ 材 8 での引張強度は Sn を含まないろう材 7 での引張強度 $230 \mathrm{MPa}$ と同じであるが，ろら材 9 での引張強度は 130 $\mathrm{MPa}$ と $100 \mathrm{MPa}$ も低下する．ところが Ag-20 mass\% $\mathrm{Al}$ 系のろら材 11,12 では, ろら材 12 での引張強度はSnを含

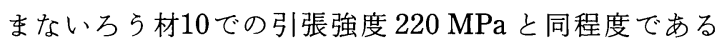

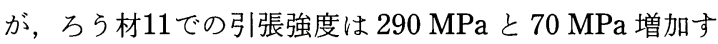
る.

ろら接継手の引張強度が大きく異なる $\mathrm{Ag}-10$ mass $\% \mathrm{Al}$ 系あるいはAg-15 mass\% Al 系ろら材では，それらのろら 接部の硬度分布はFig. 5 に見られるようにさほど大きな 相違はない。さらにろら接継手の破断位置も, Fig. 6 に示 したよらに Ag-10 mass\% Al 系ろら材の場合は $(\gamma-\delta)$ 位置 であり，Ag-15 mass\%Al 系ろら材の場合は $(\gamma$-Ti $)$ 位置と 同じである。しかしながらろら接継手の引張強度が大きく 異なるろら材では，相対する破断面からの $\mathrm{Al}, \mathrm{Ag}, \mathrm{Sn}, \mathrm{Ti}$ スペクトルの強度分布には著しい相違が認められる.

Fig. 7 に，ろら材 1, 4, 5, 8,9 の場合の相対する破断面か らの Al, Ag, Sn, Ti スペクトルの強度分布を示す.

ろら材 $1,4,5$ では継手部の破断位置はいずれも $(\gamma-\delta)$ 位 置である. したがってろら材側の破断面は $\gamma$ 相，母材側の 破断面は $\delta$ 相で構成されている. ろら材 4 では $\gamma$ 相内に 固溶している $\mathrm{Ag}$ 量が，ろら材 1 の場合と比べて多い.

一方，ろら材 5 では $\gamma$ 相内に固溶している $\mathrm{Ag}$ 量がろう 材 4 の場合と比べて非常に少なく，かつ Sn の固溶が認め られる. ろら材 4 での引張強度が $340 \mathrm{MPa}$ と非常に高く
Alloy 1
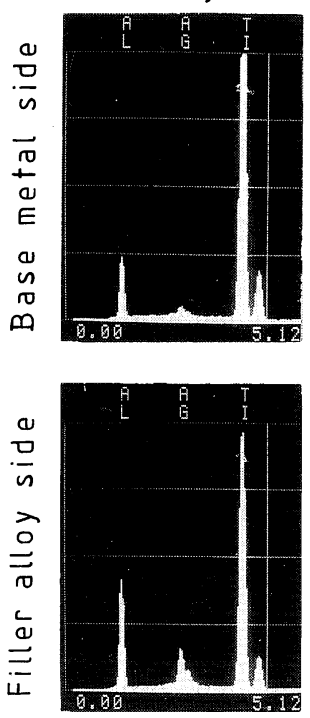

All o y 4
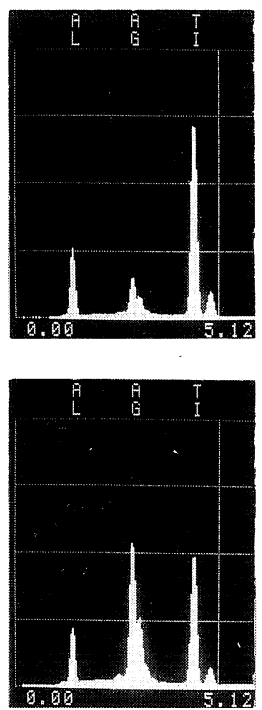

Alloy 5
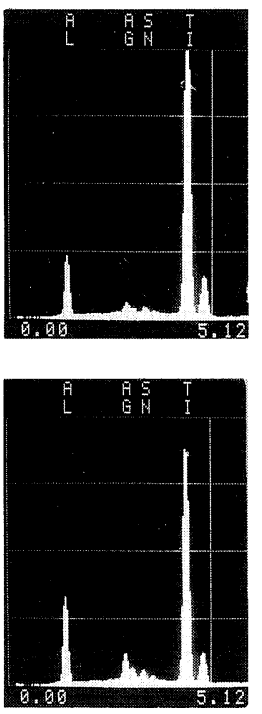

Allo y 8
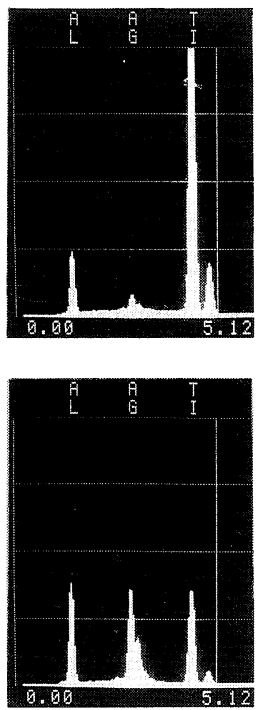

Alloy 9
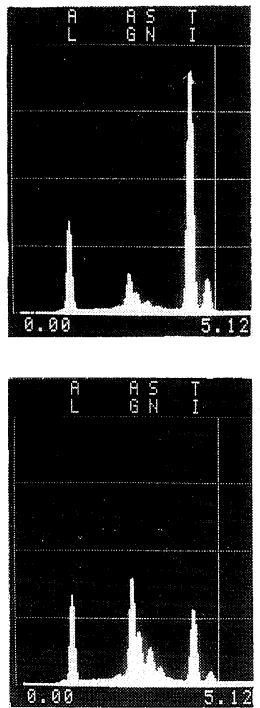

Fig. 7 Energy dispersive X-ray spectrographs of the fracture surfaces opposed each other. 
なっているのは, $\gamma$ 相内に多量の $\mathrm{Ag}$ が固溶するために $\gamma-\delta$ 相間の結合強度が増大するためと考光られる。またろ ら材 5,6 での引張強度が $170,190 \mathrm{MPa}$ と非常に低いのは, $\gamma$ 相内に Sn が固溶することにより $\gamma-\delta$ 相間の結合強度が 著しく低下するためと考えられる。

$\gamma$ 相内への Sn の固溶は， $\gamma$ 相と接する相が Ti の場合で も相間の結合強度を低下させると考光られる. Fig. 7 亿見 られるよらに, 引張強度が $230 \mathrm{MPa}$ のろら材 8 の場合は $\gamma$ 相内に Sn の固溶は認められないが, 引張強度が 130 $\mathrm{MPa}$ と非常に低いろら材 9 の場合は $\gamma$ 相内に多量の $\mathrm{Sn}$ の固溶が認められる.

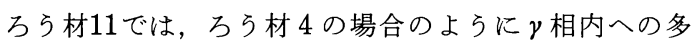
量の $\mathrm{Ag}$ の固溶が認められないにもかかわらず, 引張強度 が $290 \mathrm{MPa}$ と高い，この場合のろら接部の硬度分布は，

Fig. 5 に見られるように， 万ら材内部から母材に向かって なだらかに低下して抢り，乙かも接合界面部に形成される 化合物相の厚さは約 $1 \mu \mathrm{m}$ と非常に薄い，そのためにろら 接部でより均一な変形が起こり, $\gamma$ 相と $\delta$ 相との界面での 応力集中が軽減されていることが引張強度の増加をもたら したものと考えられる.

\section{N. 結論}

Ag-5, 10, 15, 20 mass\% $\mathrm{Al}$ 系合金に $2.5,5$ mass\% の $\mathrm{Sn}$ を添加した $\mathrm{Ag}-\mathrm{Al}-\mathrm{Sn}$ 合金のチタンろら接用低温ろら 材としての特性について検討を行った，得られた結果を以 下沶す.

(1) 万ら材中の $\mathrm{Al}$ 濃度のいかんにかかわらず $\mathrm{Sn}$ の添 加はろら材の液相線温度を低下させるのに効果がある. 5 mass\% $\%$ の の添加による液相線温度の降下は 28〜 $64 \mathrm{~K}$ で, ろら材中の $\mathrm{Al}$ 濃度が低いほど液相線温度の降下は大き い.
（2）Snを含まない $\mathrm{Ag}-\mathrm{Al}$ 系ろら材では，ろう材中の $\mathrm{Al}$ 濃度が増加するにつれてチタンに対するぬれが悪くな るが，Snを添加することによりろら材のチタンに対する ぬれが向上する.

(3) Ag-Al 系万ら材でろら接された継手の引張強度は, Ag-10 mass\%Al 万弓材の場合が $340 \mathrm{MPa}$ と最も高く, 他の場合は $220 \sim 250 \mathrm{MPa}$ と同程度である. Ag-Al 系ろ ら材への $\mathrm{Sn}$ の添加は $\mathrm{Al}$ 濃度が 5, 10, 15 mass\%万弓材の 場合は, 継手の引張強度の向上に効果がないか, 場合によ っては引張強度を $100 \sim 170 \mathrm{MPa}$ も低下させる。しかし ながら $\mathrm{Al}$ 濃度が 20 mass\%のろう材の場合は, 2.5 mass\%程度の少量の Sn の添加は引張強度の向上にとって 有効である。

(4) Ag-20 mass\% Al-2.5 mass\% $\%$ 合金をチタン用の ろら材として用いることにより， 万う接温度を $1000 \mathrm{~K}$ と チタンの $\alpha-\beta$ 变態点よりも $155 \mathrm{~K}$ 低い温度でろう接が可 能であり，さらにこの合金でろら接された継手は 290 $\mathrm{MPa}$ の引張強度が得られる.

終わりに本研究の一部は財団法人 北陸産業活性化セン ターの助成によったことを付記し，謝意を表します。

\section{文献}

(1) R. A. Long: Welding J., 33(1954), 1087.

(2) Y. Suezawa: Titanium80, 4(1980), 2407.

(3) S. W. Lan: Welding J., 61(1982), 23.

(4) X. Heberard, M. Hourcade, G. Ferriere, C. Beauvais and B. Hocheid: Titanium80, 4(1980), 2415.

( 5 ) W. T. Kaarlela and W. S. Margois: Welding J., $53(1974), 629$.

(6) T. Takemoto and I. Okamoto: J. Mater. Sci., 23 (1988), 1301.

( 7 ) C. S. Cheng, W. Y. Chang and C. T. Yu: Acta Physica Sinica, 21 (1965), 1456. 